\title{
COLONY SIZE, COMMUNICATION AND ANT FORAGING STRATEGY*
}

\author{
By R. Beckers, S. Goss, J. L. Deneubourg, J. M. Pasteels \\ Unit of Behavioural Ecology, C.P. 231, \\ Université Libre de Bruxelles, 1050 Bruxelles, Belgium
}

\section{INTRODUCTION}

Some 12,000 ant species are known by now, with colony sizes ranging from a few individuals to $20,000,000$ individuals. What constraints does this vast range of colony sizes place on the systems of organisation that they use? Alternatively, how does this range of colony sizes reflect the different systems of organisation used? We shall examine these questions in relation to ant foraging strategy, which as well as being the most visible aspect of their activity illustrates most clearly the roles and limits of communication in their collective behavior.

This paper aims to verify a prediction of the following hypothesis (Pasteels et al. 1985; Deneubourg et al. 1986). In theory, the organization of a small insect society can rely on most individuals at any moment "knowing", principally by learning, what it must do, where it must go, etc., and the workers' behavior has a strong determinist component. In a large insect society organization by individual learning is harder to achieve (Deneubourg et al. 1987). The workers' behavior is necessarily more random and their coordination becomes a major problem. To cope with this, a completely different organisational system is added to that already in place. This supplementary system is based on the complex collective structures, patterns and decisions that spontaneously emerge from simple autocatalytic interactions between numerous individuals and with the environment, mediated by essentially chemical communication (see, e.g., Pasteels et al. 1987; Goss and Deneubourg 1989; Beckers et al. in press; Deneubourg et al, 1989, in press; Goss et al. 1990).

The prediction that follows from this hypothesis is that the larger the colony size, the less foraging is individually based and the more

*Manuscript received by the editor April 5, 1989. 
the individual foragers are coordinated by mass chemical communication.

We shall use the following categories of foraging strategy that, as shall be discussed below, represent a crescendo of the integration of the individual forager into a network of communication: individual, recruitment, trunk trail and group hunting, their definitions being inspired by the work of different authors (e.g. Rosengren 1971; Wilson 1971; Leuthod 1975; Maschwitz 1975; Oster \& Wilson 1978; Moffet 1988; Traniello 1989).

By individual foraging we mean foraging without systematic cooperation or communication in the discovery, capture or transport of prey items. Each forager leaves the nest, searches for food and transports it individually (e.g. Cataglyphis bicolor, Pachycondyla apicalis).

By foraging with recruitment, we mean that a scout having discovered a food item returns to the nest and transmits the information concerning its location to inactive foragers waiting in the nest. These recruits can become recruiters in their turn. It should be noted that recruiting species rely to a large extent on individual foraging for the discovery and exploitation of small sources.

Roughly speaking, three recruitment types can be distinguished. With tandem recruitment, the scout guides one recruit to the food item, with or without trail laying (e.g. Leptothorax sp.). With mass recruitment, a trail laid by the recruiter while returning to the nest guides recruits to the food (e.g. Solenopsis invicta, Monomorium pharaonis). Invitation by the recruiter in the nest is often active. With group recruitment, the scout guides a group of nestmates, in some cases (if not all) laying a pheromone trail to the nest (e.g. Tetramorium caespitum, Camponotus socius). However, as every species that we know uses group recruitment also uses a more or less efficient mass recruitment, we shall refer to group/mass recruitment. Note that some authors distinguish a fourth recruitment system, group raiding (type IV-Oster and Wilson 1978), which is characterised by a very strong invitation and recruitment trail that results in a large group of recruits leaving the nest together in a rush. We have included this system in group/mass recruitment.

With trunk trails, semi-permanent trails guide foragers to longlasting food sources (e.g. many Formica sp.), and also serve as starting-off points for individual foragers, which may also recruit to 
the trunk-trails. Finally, group hunting foragers (sensu Moffet 1988, including army ants) leave the nest and forage collectively in a swarm along a well-defined trail system that is constructed as the swarm progresses (e.g. Dorylinae sp.).

These descriptions are by no means meant to be definitive, and there are of course species whose foraging does not fall neatly into one or indeed any of these categories. Nevertheless, as shall be discussed below, they represent a crescendo of the integration of the individual forager into a network of communication. Other recruitment systems are known to exist (such as short-distance recruitment or non-directional recruitment), but for lack of data have been omitted. Similarly, the colony sizes given are average figures, obtained by different techniques, and generally with rather small sample sizes. Polycalic societies pose a special problem. For these reasons, the values quoted must be considered only as firstorder approximations.

\section{RESUlts AND Discussion}

Table 1 presents the colony size and foraging system of 98 different species. Fig. 1 presents the foraging system as a function of the colony size. Although that data base is small compared to the number of known ant species, a distinct trend is clear (note the logarithmic scale). The smaller societies rely on individual foragers that do not transmit their discoveries. The largest societies rely on permanent chemical communication between the individuals. Between these two limits, one finds the different types of recruitment. Again, the smaller recruiting societies rely on a slow, individual recruitment, where a recruiter interacts directly with one or a few individuals. The larger recruiting societies rely on the faster mass recruitment, where one recruiter can interact via a chemical trail with a large number of potential recruits. The trail transmits both the position of the source and that of the nest to the recruits. Note that we have listed the species in Table 1 by alphabetical order for facility, and that the same tendency appears in each sub-family.

Taking these results into consideration we propose two extreme blueprints for the way in which ants organise their foraging.

The first blueprint consists of small societies which rely on the capacity for learning of its members to exploit the foraging area efficiently. Individual foragers, for example, develop fidelity to 
parts of their foraging area and can orient themselves over large distances (Wehner et al. 1983; Fresneau 1985). They do not interact directly with each other, nor do they communicate their food discoveries, yet they are capable of dividing the foraging area amongst themselves (Deneubourg et al. 1987). The society may be considered to have placed its complexity at the level of the individual.

The second blueprint consists of large societies whose individual behavior may be considered as simple. They rely on a highly developed network of chemical communication based on permanent trail-laying behavior to coordinate the foragers' activity and to aid their orientation. Their capacity for individual orientation is limited not only because it is not so needed as the trails are there, but also because too much individuality could prevent collective foraging from functioning efficiently. It is surely no coincidence that the largest and most chemically integrated societies, i.e. the different army ants and termites, are practically blind. The colony size is large, not simply to ensure that their "inefficient" workers manage to perform the necessary tasks by sheer weight of numbers (Oster and Wilson 1978; Herbers 1981), but because they need a large reserve of individuals for the amplifying mechanisms (e.g. recruitment) by which they structure their foraging to work (e.g. Pasteels et al. 1987). The society may be said to have placed its complexity more at the level of the interactions between individuals.

Between these two extremes, we find intermediate sized societies which rely on individual scouts to forage small food items and on recruitment to amplify the information relating to important food sources. The sequence tandem/group-mass/mass is characterised by an increasing number of individuals that react to the recruiters' signals, and is associated with an increasing colony size. In mass recruiting species there is a tendency in the largest societies to lay trail pheromone not only when returning with food but also when leaving the nest and more or less continually in the foraging area (e.g. Pheidole militicida - Hölldobler and Möglich 1980; Iridomyrmex humilis - Van Vorhis Key and Baker 1986; Aron et al. 1989).

There is of course a large degree of overlapping between the different categories in fig. 1 . This is to be expected whenever one tries to categorize nature, but is also the result of imprecision in our knowledge of colony size, which is anyway highly variable for a 


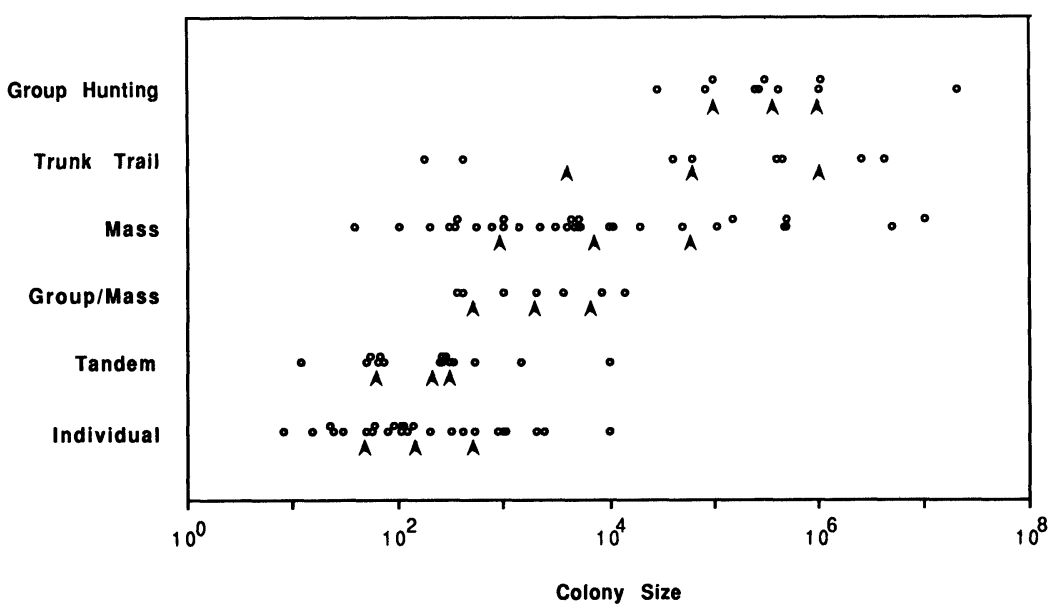

Fig. 1. Foraging strategy as a function of colony size for 98 ant species (see Table 1). The arrows mark the 25,50 (median) and 75 percentiles.

given species. Furthermore, others factors such as the size, distribution and type of food exploited intervene, and ant foraging strategy and food type are obviously connected (e.g. Carrol and Janzen 1973; Traniello 1989).

Other less precise data confirm the tendency seen in fig. 1. For example we know that Crematogaster ashmeadi colonies are very large and that they use mass recruitment (Leuthold 1968a, b), whereas Bothroponera tesserinoda colonies are small and use tandem recruitment foraging.

The same overall tendency as shown here for ant species, also noted by Buschinger (1980) for dulotic ants, is well known in the Apidae. Species with small colonies, such as bumblebees, use an individual foraging strategy. Those with large colonies, such as honeybees, melipones and trigones, use recruitment (Lindauer and Kerr 1958; Seeley 1985). The tendency is also observed in terns (Erwin 1978).

We would like to end this paper with an appeal to readers to help us increase the size of our data base. We would welcome any information about colony size and foraging system, whether for species already in Table 1 or for any other ant species. 
Table 1. Average colony size and foraging strategy of 98 ant species. The subfamilies (in brackets) are: $1=$ Aneuretinae, $2=$ Cerapachyinae, $3=$ Dolichoderinae, $4=$ Dorylinae, $5=$ Formicinae, $6=$ Leptanillinae, $7=$ Myrmeciinae, $8=$ Myrmicinae, $9=$ Ponerinae, $10=$ Pseudomyrmecinae. The foraging types are: $\mathrm{I}=$ Individual, $\mathrm{TR}=$ Tandem recruitment, $\mathrm{GM}=$ Group $/$ Mass recruitment, $\mathrm{MR}=$ Mass recruitment, $\mathrm{TT}=$ Trunk trail, $\mathrm{GH}=$ Group hunting.

\begin{tabular}{|c|c|c|c|}
\hline Species (subfamily) & Nest Size & $\begin{array}{l}\text { Frg. } \\
\text { Type }\end{array}$ & References \\
\hline Acromyrmex landolti (8) & 1,000 & MR & Jaffe pers. comm. \\
\hline octospinosus & 50,000 & MR & $\begin{array}{l}\text { Blum et al. 1964; } \\
\text { Jaffe pers. comm. }\end{array}$ \\
\hline Aenictus laeviceps (4) & 85,000 & GH & Schneirla 1965 \\
\hline Amblyopone pallipes (9) & 15 & I & $\begin{array}{l}\text { Traniello 1978; Lachaud } \\
\text { pers. comm. }\end{array}$ \\
\hline Aneuretis simoni (1) & 40 & MR & $\begin{array}{l}\text { Traniello and Jayasuriya 1981; } \\
\text { Jayasuria and Traniello } 1985\end{array}$ \\
\hline Anomma nigricans (4) & $1,036,800$ & GH & Vosseler 1905 \\
\hline wilverthi & $20,000,000$ & GH & Raignier and van Boven 1955 \\
\hline Atta cephalotes (8) & 500,000 & MR & $\begin{array}{l}\text { Jaffe and Howse 1979; } \\
\text { Jaffe pers. comm. }\end{array}$ \\
\hline sexdens & $5,000,000$ & MR & $\begin{array}{l}\text { Riley et al. 1974; } \\
\text { Jaffe pers. comm. }\end{array}$ \\
\hline texana & $10,000,000$ & MR & $\begin{array}{l}\text { Moser and Blum 1963; Riley } \\
\text { et al. 1974; Jaffe pers. comm. }\end{array}$ \\
\hline Azteca foreli (3) & 50,000 & MR & Jaffe pers. comm.; \\
\hline Camponotus aethiops (5) & 2,500 & I & Suzzoni pers. comm. \\
\hline pennsylvanicus & 2,200 & MR & Pricer 1908; Traniello 1977 \\
\hline sericeus & 250 & TR & Hölldobler et al. 1974 \\
\hline truncatus & 50 & I & Suzzoni pers. comm. \\
\hline Cataglyphis bicolor (9) & 2,000 & I & Wehner et al. 1983 \\
\hline cursor & 1,000 & I & $\begin{array}{l}\text { Cagniant 1983; } \\
\text { Lenoir pers. comm. }\end{array}$ \\
\hline Conomyrma bicornis (3) & 5,000 & MR & Jaffe pers. comm. \\
\hline Crematogaster sumicrasti (8) & 1,000 & MR & Jaffe pers. comm. \\
\hline Cyphomyrmex rimosus (8) & 100 & I & $\begin{array}{l}\text { Blum et al. 1964; } \\
\text { Jaffe pers. comm. }\end{array}$ \\
\hline Daceton armigerum $(8)$ & 10,000 & I & $\begin{array}{l}\text { Blum and Portocarrero 1965; } \\
\text { Jaffe pers. comm. }\end{array}$ \\
\hline Diacamma rugosum (9) & 100 & I & Fukumoto and Abe 1983 \\
\hline Dinoponera australis (9) & 30 & I & Fowler 1985 \\
\hline quadriceps & 60 & I & Dantas de Araujo pers. comm. \\
\hline Eciton burchelli (4) & 425,000 & GH & Schneirla 1957 \\
\hline hamatum & 300,000 & GH & Schneirla 1957; Rettenmeyer 1963 \\
\hline rapax & 275,000 & $\mathrm{GH}$ & Sudd and Franks 1987 \\
\hline Ectatomma ruidum $(9)$ & 125 & I & Lachaud et al. 1984 \\
\hline Erebomyrma nevermanni (8) & 180 & TT & Wilson 1986 \\
\hline
\end{tabular}


Table 1. Continued

\begin{tabular}{|c|c|c|c|}
\hline Species (subfamily) & Nest Size & $\begin{array}{l}\text { Frg. } \\
\text { Type }\end{array}$ & References \\
\hline Formica aquilonia (5) & 400,000 & TT & Zakharov 1978 \\
\hline bruni & 1,400 & MR & $\begin{array}{l}\text { Cherix and Maddalena-Feller } \\
1987\end{array}$ \\
\hline cunicularia & 1,100 & I & Deffernez pers. comm. \\
\hline fusca & 500 & MR & $\begin{array}{l}\text { Wallis 1964; } \\
\text { Möglich and Hölldobler } 1975\end{array}$ \\
\hline lugubris & 40,000 & TT & Rosengren 1971; Breen 1979 \\
\hline polyctena & 450,000 & TT & $\begin{array}{l}\text { Rosengren 1971; Kruk-de-Bruin } \\
\text { et al. 1977; Horstmann } 1982\end{array}$ \\
\hline pratensis & 60,000 & TT & Rosengren 1971; Jensen 1977 \\
\hline rufa & $4,000,000$ & TT & Gösswald 1951; Rosengren 1971 \\
\hline yessensis & 51,000 & TT & Ito 1973 ; Cherix 1987 \\
\hline Iridomyrmex humilis (3) & 150,000 & MR & Keller pers. comm. \\
\hline Labidus praedator (4) & $1,000,000$ & $\mathrm{GH}$ & Rettenmeyer 1963 \\
\hline Lasius fuliginosus (5) & $2,500,000$ & TT & $\begin{array}{l}\text { Hainaut-Riche et al. } 1980 \text {; } \\
\text { Quinet et Pasteels } 1987 .\end{array}$ \\
\hline niger & 5,500 & MR & Stradling 1970; Brian 1977 \\
\hline Leptogenys chinensis (9) & 367 & GM & Maschwitz and Schönegge 1983 \\
\hline ocellifera & 50,000 & MR & Maschwitz and Mühlenberg 1975 \\
\hline Leptothorax acervorum (8) & 250 & TR & $\begin{array}{l}\text { Dobrzanski 1966; Büschinger } \\
\text { 1971; Möglich et al. 1974; } \\
\text { Möglich } 1979\end{array}$ \\
\hline ambiguus & 50 & TR & Talbot 1965; Möglich 1979 \\
\hline curvispinosus & 50 & TR & $\begin{array}{l}\text { Headley 1943; Talbot 1965; } \\
\text { Möglich } 1979\end{array}$ \\
\hline duloticus & 12 & TR & $\begin{array}{l}\text { Talbot 1957; Alloway 1979; } \\
\text { Möglich } 1979\end{array}$ \\
\hline longispinosus & 65 & TR & Headley 1943 \\
\hline muscorum & 300 & TR & $\begin{array}{l}\text { Büschinger 1966; Möglich et al. } \\
1974\end{array}$ \\
\hline nylanderi & 280 & TR & Plateau pers. comm. \\
\hline unifasciatus & 325 & TR & Lane 1977; Plateau pers. comm. \\
\hline Messor barbara $(8)$ & 8,000 & GM & Delye pers. comm. \\
\hline sancta & 3,500 & GM & $\begin{array}{l}\text { Delye pers. comm.; } \\
\text { Suzzoni pers. comm. }\end{array}$ \\
\hline Monomorium pharaonis & 800 & MR & Peacock et al. 1955; Sudd 1960 \\
\hline Myrmecia gulosa (7) & 900 & I & $\begin{array}{l}\text { Haskins and Haskins 1950; } \\
\text { Robertson 1971 }\end{array}$ \\
\hline Myrmica rubra (8) & 1,000 & GM & $\begin{array}{l}\text { Stradling 1970; Petal 1972; } \\
\text { Cammaerts and Cammaerts } 1980\end{array}$ \\
\hline ruginodis & 2,000 & GM & $\begin{array}{l}\text { Stradling 1970, Brian 1972; } \\
\text { Cammaerts and Cammaerts } 1980\end{array}$ \\
\hline sabuleti & 3,000 & MR & $\begin{array}{l}\text { Brian 1972; } \\
\text { Cammaerts and Cammaerts } 1980\end{array}$ \\
\hline
\end{tabular}


Table 1. Continued

\begin{tabular}{|c|c|c|c|}
\hline Species (subfamily) & Nest Size & $\begin{array}{l}\text { Frg. } \\
\text { Type }\end{array}$ & References \\
\hline Myrmicaria eumenoides (8) & 20,000 & MR & Levieux 1983 \\
\hline Myrmoteras barbouri (5) & 8 & I & Moffet 1986a \\
\hline toro & 22 & I & Moffet 1986a \\
\hline Neivamyrex nigrescens (4) & 30,000 & GH & Topoff et al. 1980 \\
\hline Novomessor cockerelli (8) & 350 & MR & Hölldobler et al. 1978. \\
\hline albicetosus & 350 & MR & Hölldobler et al. 1978. \\
\hline Ocymyrmex barbiger (8) & 200 & MR & Marsh 1985 \\
\hline Odontomachus bauri (9) & 300 & I & Jaffe and Marcuse 1983 \\
\hline haematoda & 500 & TR & $\begin{array}{l}\text { Hölldobler and Engel 1978; } \\
\text { Jaffe pers. comm. }\end{array}$ \\
\hline troglodytes & 240 & TR & $\begin{array}{l}\text { Dejean 1982; } \\
\text { Dejean and Bashingwa } 1985\end{array}$ \\
\hline Oecophylla longinoda (5) & 480,000 & MR & $\begin{array}{l}\text { Way 1954; } \\
\text { Hölldobler and Wilson } 1978\end{array}$ \\
\hline Ophthalmopone berthoudi (9) & 400 & I & Peeters and Crewe 1987 \\
\hline Ologomyrmex overbecki (8) & 400 & TT & Moffet 1986b \\
\hline Pachycondyla apicalis (9) & 90 & I & $\begin{array}{l}\text { Lachaud et al. 1984; } \\
\text { Fresneau } 1985\end{array}$ \\
\hline caffraria & 70 & TR & Lévieux 1967; Agbogba 1981 \\
\hline commutata & 400 & GM & Mill 1982, 1984 \\
\hline obscuricornis & 100 & I & $\begin{array}{l}\text { Traniello and Hölldobler 1984; } \\
\text { Fresneau } 1984\end{array}$ \\
\hline villosa & 500 & I & $\begin{array}{l}\text { Lachaud et al. 1984; } \\
\text { Lachaud pers. comm. }\end{array}$ \\
\hline Pheidole embolopyx (8) & 300 & MR & Wilson and Hölldobler 1985 \\
\hline fallax & 10,000 & MR & $\begin{array}{l}\text { Law et al. } 1965 \\
\text { Jaffe pers. comm. }\end{array}$ \\
\hline pallidula & 5,000 & MR & Detrain pers. comm. \\
\hline Pheidologeton diversus (8) & 250,000 & GH & Moffet 1988 \\
\hline silenus & 100,000 & GH & Moffet 1988 \\
\hline Pogonomyrmex badius (8) & 4,300 & MR & $\begin{array}{l}\text { Brian et al. 1967; } \\
\text { Hölldobler and Wilson } 1970\end{array}$ \\
\hline californicus & 4,500 & MR & $\begin{array}{l}\text { Hölldobler and Wilson 1970; } \\
\text { Erickson } 1972\end{array}$ \\
\hline occidentalis & 3,880 & MR & $\begin{array}{l}\text { Lavigne 1969; } \\
\text { Hölldobler and Wilson } 1970\end{array}$ \\
\hline Ponera eduardi (9) & 1,500 & TR & Le Masne 1952; Bernard 1968 \\
\hline Proatta butteli (8) & 10,000 & MR & Moffet 1986c \\
\hline Pseudomyrmex termitarius (10) & 75 & TR & Jaffe pers. comm. \\
\hline triplarinus & 10,000 & TR & Jaffe pers. comm. \\
\hline Serrastruma lujae (8) & 57 & I & Dejean 1982 \\
\hline serrula & 78 & I & Dejean 1982 \\
\hline
\end{tabular}


Table 1. Continued

\begin{tabular}{|c|c|c|c|}
\hline Species (subfamily) & Nest Size & $\begin{array}{l}\text { Frg. } \\
\text { Type }\end{array}$ & References \\
\hline Smithistruma emarginata (8) & 199 & I & Dejean 1982 \\
\hline truncatidens & 133 & I & Dejean 1982 \\
\hline Solenopsis invicta $(8)$ & 100,000 & MR & Wilson 1962; Tschinkel 1987 \\
\hline Tapinoma erraticum (3) & 1,000 & MR & $\begin{array}{l}\text { Meudec 1979; } \\
\text { Verhaeghe et al. } 1980\end{array}$ \\
\hline Tetramorium caespitum (8) & 14,000 & GM & $\begin{array}{l}\text { Brian et al. } 1967 \\
\text { Pasteels et al. } 1987\end{array}$ \\
\hline Trachymyrmex urichi (8) & 100 & MR & $\begin{array}{l}\text { Jaffe and Villegas } 1985 \\
\text { Jaffe pers. comm. }\end{array}$ \\
\hline Zacryptocerus varians (8) & 1,000 & MR & Wilson 1976; Jaffe pers. comm. \\
\hline
\end{tabular}

\section{ACKNOWLEDGMENT}

Drs. G. Delye, D. Fresneau, K. Jaffe, L. Keller, J. P. Lachaud, L. Plateau and J.-P. Suzzoni kindly sent us unpublished information. This work is supported in part by the Belgian program on interuniversity attraction poles and Les Instituts Internationaux de Physique et de Chimie.

\section{SUMMARY}

The foraging strategy of 98 ant species is examined in relation to their colony size. Six foraging strategies are distinguished, namely indivdual, tandem, group/mass and mass recruitment, trunk trail, and army ant type, and are seen to be associated with increasing colony size. This supports the hypothesis that the larger the colony, the more the individual worker is integrated into a network of chemical communication. Two extreme organisational blueprints are proposed. The first consists of small societies which rely on the capacity for learning of its members to exploit the foraging area efficiently. The second relies on the complex collective patterns that spontaneously emerge from chemically mediated recruitment processes interacting with the environment. 


\section{REFERENCES (TEXT)}

Aron, S., J. M. Pasteels and J. L. Deneubourg

1989. Spatial organisation in the Argentine ant, Iridomyrmex humilis (Mayr). Biol. Behav. 14: 207-217.

Beckers, R., J. L. Deneubourg, S. Goss, and J. M. Pasteels

In press. Collective decision making through food recruitment. Ins. Soc.

BUSCHINGER, A., W. EHRHARDT, AND U. WINTER

1980. The organisation of slave raids in dulotic ants-a comparative study (Hymenoptera; Formicidae). Z. Tierpsychol., 53: 245-264.

Carrol, C., and D. H. Janzen

1973. Ecology of foraging by ants. Annu. Rev. Ecol. Syst., 4: 231-257.

Deneubourg, J. L., S. Aron, S. Goss, J. M. Pasteels, and G. Duerinck

1986. Random behaviour, amplification process and number of participants. How they contribute to the foraging properties of ants. Evolution, Games and Learning (D. Farmer, A. Lapedes, N. Packard and B. Wendroff, eds.), 176-186, Physica D 22.

Deneubourg, J. L., S. Goss, J. M. Pasteels, D. Fresneau and J.-P. Lachaud

1987. Self-organization mechanisms in ant societies (II): Learning in foraging and division of labor. From Individual To Collective Behaviour In Social Insects (J. M. Pasteels and J. L. Deneubourg, eds.), 177-196, Birkhäuser, Basel.

Deneubourg, J. L., S. Aron, S. Goss, and J. M. Pasteels

In press. The self-organizing exploratory pattern of the Argentine ant Iridomyrmex humilis. J. Ins. Behav.

Deneubourg, J. L., S. Goss, N. Franks and J. M. Pasteels

1989. The blind leading the blind: modelling chemically mediated army ant raid patterns. J. Ins Behav. 2: 719-725.

ERWIN, M.

1978. Coloniality in terns: the role of social feeding. Condor 80: 211-215.

Fresneau, D.

1985. Individual foraging and path fidelity in a Ponerine ant. Ins. Soc. 32: 109-116.

Goss, S. And J. L. Deneubourg

1989. The self-organisation clock pattern of Messor pergandei (Formicidae, Myrmicinae). Ins. Soc. 36: 339-246.

Goss, S., S. Aron, J. L. Deneubourg and J. M. Pasteels

1990. Self-organised short-cuts in the Argentine ant. Naturwissenschaften 76 .

Herbers, J. M.

1981. Reliability theory and foraging by ants. J. Theor. Biol 89: 175-189.

Hölldobler, B, AND M. Möglich.

1980. The foraging system of Pheidole militicida (Hymenoptera: Formicidae). Ins. Soc. 27: 399-415.

LEUTHOLD, R. H.

1968. A tibial gland scent-trail and trail-laying behavior in the ant Crematogaster ashmeadi. Psyche 75: 233-248. 
LEUTHOLD, R. H.

1968. Recruitment to food in the ant Cremastogaster ashmeadi. Psyche 75: 334-350.

LEUTHOLD, R. H.

1975. Orientation mediated by pheromones in social insects. Proc. Symp. IUSSI. Pheromones and defensive secretions in social insects (P. Noirot, P. Howse and G. Le Masne, eds.), 197-211, Université de Dijon.

Lindauer, M. AND W. E. KerR

1958. Die gegenseitige Verständigung bei den stachellosen Bienen. Z. vergl. Physiol. 41: 405-434.

MaschWitz, U.

1975. Old and new trends in the investigation of chemical recruitment in ants. Proc. Symp. IUSSI. Pheromones and defensive secretions in social insects (P. Noirot, P. Howse and G. Le Masne, eds.), 47-59, Université de Dijon.

MOFFET, M. W.

1988. Foraging dynamics in the group-hunting myrmicine ant, Pheidologeton diversus. J. Ins. Behav. 1: 309-331.

OSTER, G. F., AND E. O. WILSON

1978. Caste and Ecology in the Social Insects. Princeton University Press, Princeton.

Pasteels, J. M., J. L. Deneubourg and S. Goss

1985. Transmission and amplification of information in a changing environment: the case of insect societies. Laws of Nature in Human Conduct (I. Prigogine and M. Sanglier, eds.), 129-156, G.O.R.D.E.S., Brussels.

Pasteels, J. M., J. L. Deneubourg and S. Goss

1987. Self-organization mechanisms in ant societies (I): Trail recruitment to newly discovered food sources. From Individual To Collective Behaviour In Social Insects (J. M. Pasteels and J. L. Deneubourg, eds.), 155-176, Birkhäuser, Basel.

ROSENGREN, R.

1971. Route fidelity, visual memory and recruitment behaviour in foraging wood ants of the genus Formica (Hym., Formicidae). Act. Zool. Fenn. 133: $1-106$.

SEeley, T. D.

1985. Honeybee Ecology. Princeton University Press, Princeton.

Traniello, J. R.

1989. Foraging strategies in ants. Ann. Rev. Entomol. 34: 191-210.

VAN Vorhis Key, S. E., AND T. C. BAKer

1986. Observations on the trail deposition and recruitment behaviors of the Argentine ant, Iridomyrmex humilis (Hymenoptera: Formicidae). Ann. Entomol. Soc. Am. 79: 283-288.

Wehner, R., R. D. Harkness and P. SChmid-Hempel

1983. Foraging strategies in individually searching ants Cataglyphis bicolor. Gustav Fischer Verlag, Stuttgart.

WILSON, E. O.

1971. The Insect Societies. Harvard University Press, Cambridge (Mass.). 


\section{REFERENCES (TABLE I)}

Agbogba, C.

1981. L'approvisionnement en proies chez quelques espèces de fourmis. Coll. UIEIS, sect franç., Toulouse, 18-22.

Alloway, T. M.

1979. Raiding behaviour of two species of slave making ants: Harpagoxenus americanus (Emery) and Leptothorax duloticus Wesson (Hymenoptera: Formicidae). Anim. Behav. 27: 202-210.

BERNARD, F.

1968. Les Fourmis d'Europe Occidentale et Septentrionale. Masson et Cie, Paris.

Blum, M. S. and C. A. Portocarrero

1966. Chemical releasers of social behavior. X. An attine trail substance in the venom of a non-trail laying myrmicine, Daceton armigerum (Latreille) Psyche 73: 150-155.

Blum, M. S., J. C. Moser and A. D. Cordero

1964. Chemical releasers of social behaviour. II. Source and specificity of the odor trail in four Attine genera. (Hym., Form.). Psyche 71: 1-7.

Breed, M. D. AND B. BenNeTt

1985. Mass recruitment to nectar sources in Paraponera clavata: A field study. Ins. Soc. 32: 198-208.

BreEN, J.

1979. Worker populations of Formica lugubris Zett. nests in Irish plantation woods. Ecol. Entomol. 4: 1-7.

BriAN, M. V.

1972. Population turnover in wild colonies of the ant Myrmica. Ekol. Pol. 20: 43-53.

BRIAN, M. V.

1977. Ants. The new naturalist, Collins, London.

Brian, M. V., G. Elmes and A. F. Kelly

1967. Populations of the ant Tetramorium caespitum Latreille. J. Anim. Ecol. 36: 337-342.

BüsCHINGER, A.

1966. Untersuchungen an Harpagoxenus sublaevis Nyl. (Hym., Formicidae). I. FreilandBonn. Zool. Beitr. 22: 322-331.

BÜSCHINGER, A.

1971. Zur Verbreitung der Sozialparasiten von Leptothorax acervorum (Fabr.) (Hym., Form.). Bonn. Zool. Beitr. 22: 322-331.

Cagniant, $\mathrm{H}$.

1983. La Parthénogenèse Thélytoque et Arrhénotoque des ouvrières de la fourmi Cataglyphis cursor (Fonscolombe) (Hym. Form.). Etude biométrique des ouvrières et de leurs potentialités reproductrices. Ins. Soc. 30: 241-254.

Cammaerts, M. C. and R. Cammaerts

1980. Food recruitment strategies of the ants Myrmica sabuleti and M. ruginodis. Behav. Processes. 5: 251-270. 
Cherix, D.

1987. Relation between diet and polyethism in Formica colonies. From Individual To Collective Behaviour In Social Insects (J. M. Pasteels and J. L. Deneubourg, eds.), 155-176, Birkhäuser, Basel.

Cherix, D. and C. Maddalena-Feller

1987. Foraging strategy in Formica bruni in relation to colony structure: An important step towards polycalism. Chemistry and Biology of Soil Insects (J. Eder and H. Rembold, eds.), 515-516 Verlag Peperny, München.

Dejean, A.

1982. Quelques aspects de la prédation chez les fourmis de la tribu des Dacetini. (Formicidae-Myrmicinae). Thèse de Doctorat d'Etat. Université Paul Sabatier, Toulouse.

Dejean, A. and E. P. Bashingwa

1985. La prédation chez Odontomachus troglodytes Santschi (FormicidaePonerinae). Ins. Soc. 32: 23-42.

DobrZanski, J.

1966. Contribution to the ethology of Leptothorax acervorum. Acta Biol. Exper. (Warsaw) 26: 71-78.

ERICKSON, J. M.

1972. Mark-recapture techniques for population estimates of Pogonomyrmex ant colonies: an evaluation of the $\mathrm{P}^{32}$ technique. Ann. Ent. Soc. Am. 65: 57-61.

FOWLER, H. G.

1985. Populations, foraging and territoriality in Dinoponera australis (Hymenoptera, Formicidae). Revta bras. Ent. 29: 443-447.

Fresneau, D.

1984. Développement ovarien et statut social chez une fourmi primitive Neoponera obscuricornis Emery (Hym. - Form., Ponerinae). Ins. Soc. 31: 387-402.

Fresneau, D.

1985. Individual foraging and path fidelity in a ponerine ant. Ins. Soc. 32: 109-116.

FuKumoto, Y. AND T. ABE

1983. Social organization of colony movement in the tropical ponerine ant Diacamma rugosum. J. Ethol. 1: 101-108.

Gösswald, K.

1951. Die rote Waldameise im Dienste der Waldhygiene. Lüneburg: Metta Kinau Verlag.

Hainaut-Riche, B., G. Josens and J. M. Pasteels

1980. L'approvisionnement du nid chez Lasius fuliginosus: pistes, cycles d'activité et spécialisation territoriale des ouvrières. C. R. UIEIS sect. franç. Lausanne, 71-78.

Haskins, C. P. AND E. H. Haskins

1950. Notes on the biology and social behavior of the archaic Ponerine ants of the genera Myrmecia and Promyrmecia. Ann. ent. Soc. Am., 43: 461-491. 
HeAdley, A. E.

1943. Population studies of two species of ants, Leptothorax longispinosus and Leptothorax curvispinosus Mayr. Ann. Entomol. Soc. Amer. 36: 743-753.

Hölldobler, B. AND ENGEL

1978. Tergal and sternal glands in ants. Psyche 85: 285-330.

HöLLDOBLER, B. AND E. O. WILSON.

1970. Recruitment Trails in the harvester ant Pogonomyrmex badius. Psyche 77: 385-399.

HÖLLDOBLER, B. AND E. O. WILSON

1978. The multiple recruitment systems of the african weaver ant Oecophylla longinoda. Behav. Ecol. Sociobiol. 3: 19-60.

Hölldobler, B., M. Möglich aNd U. Maschitz

1974. Communication by Tandem Running in the ant Camponotus sericeus. J. Comp. Physiol. 90: 105-127.

Hölldobler, B., R. C. Stanton and H. Markul

1978. Recruitment and food-retrieving behavior in Novomessor (Formicidae, Hymenoptera). Behav. Ecol. Sociobiol. 4: 163-181.

Horstmann, K.

1982. Die Energiebilanz der Waldameisen (Formica polyctena Förster) in einem Eichenwald. Ins. Soc. 29: 402-421.

Iто, $\mathrm{M}$.

1973. Seasonal population trends and nest structure in a polydomous ant, Formica (Formica) yessensis Forel (Hym., Formicidae). J. Fac. Sci. Hokkaido Univ., Ser. VI, Zool., 19: 270-293.

JAFFe, K. AND P. E. HowsE

1979. The mass recruitment system of the leaf-cutting ant Atta cephalotes (L.). Anim. Behav., 27: 930-939.

JAFFE, K. AND M. MARCUSE

1983. Nestmate recognition and territorial behaviour in the ant Odontomachus bauri Emery (Formicidae Ponerinae). Ins. Soc. 30: 466-481.

JAFFE, K., AND G. Villegas

1985. On the communication system of the fungus growing ant Trachimyrmex urichi. Ins. Soc. 32: 257-274.

Jayasuria, A. K. and J. F. A. Traniello

1985. The Biology of the primitive ant Aneuretus simoni (Emery) (Formicidae: Aneuretinae). I. Distribution, abundance, colony structure, and foraging ecology. Ins. Soc. 32: 363-375.

JENSEN, T. F.

1977. Annual foraging activity of a colony of Formica pratensis Retz. Proceedings VIIIth International Congress IUSSI, Wageningen, 217-218.

Kruk-De-Bruin, M., L. C. M. Rost and F. G. A. M. Draisma

1977. Estimates of the number of foraging ants with the Lincoln-index method in relation to the colony size of Formica polyctena. J. Anim. Ecol. 46: 457-470.

Lachaud, J. P., D. Fresneau and J. Garcia-Perez

1984. Etude des stratégies d'approvisionnement chez 3 espèces de fourmis ponerines (Hym.: Formicidae). Folia Entomol. Mex. 61: 159-177. 
LANE, A.

1977. Recrutement et orientation chez la fourmi Leptothorax unifasciatus (Latr.): Rôle de la piste et des tandems. Thèse de 3e cycle, Dijon, p. 124.

LAVIGNE, R. J.

1969. Bionomics and nest structure of Pogonomyrmex occidentalis. Ann. Ent. Soc. Am. 62: 1166-1175.

Law, J. H., A. Raignier, AND E. O. Wilson.

1965. Biochemical polymorphism in ants. Science 149: 544-546.

LEMASNE, G.

1952. Les échanges alimentaires entre adultes chez la fourmi Ponera eduardi Forel. C. R. Acad. Sci. Paris D 235: 1549-1551.

LeVIEUX, J.

1983. Mode d'exploitation des ressources alimentaires épigées de savanes africaines par la fourmi Myrmicaria eumenoides Gerstaecker. Ins. Soc. 30: 165-176.

MARSh, A. C.

1985. Microclimatic factors influencing foraging patterns and success of the thermophilic desert ant, Ocymyrmex barbiger. Ins. Soc. 32: 286-296.

MaSChWITZ, U. AND M. MÜHLENBERG

1975. Zur Jagdstrategie einiger orientalischer Leptogenys-Arten (Formicidae: Ponerinae). Oecologia 20: 65-83.

MaSChWITZ, U. AND P. SCHÖNEGGE

1983. Foraging communication, nest moving recruitment and prey specialization in the oriental ponerine Leptogenys chinensis. Oecologia 57: $175-182$.

Meudec, M.

1979. Comportement d'émigration chez la fourmi Tapinoma erraticum (Form. Dolichoderinae). Un exemple de régulation sociale. Thèse, Université de Tours.

MiLL, A. E.

1982. Emigration of a colony of the giant Termite hunter Pachycondyla communata (Roger) (Hymenoptera: Formicidae). Entomologist's monthly magazine 118: 243-245.

MILL, A. E.

1984. Predation by the Ponerine ant Pachycondyla communata on termites of the genus Syntermes in Amazonian rain forest. J. Nat. Hist. 18: 405-410.

MOFFET, M. W.

1986a. Trap-jaw predation and other observations on two species of MyrmoteMOFFET, M. W. ras (Hymenoptera: Formicidae). Ins. Soc. 33: 85-99.

1986b. Notes on behavior of the dimorphic ant Oligomyrmex overbecki MOFFET, M. W. (Hymenoptera: Formicidae). Psyche 93: 107-116.

1986c. Behavior of the group predatory ant Proatta butteli (Hymenoptera: Formicidae): an old world relative of the attine ants. Ins. Soc. 33: 444-457. 
MOFFET, M. W.

1988. Nesting, emigrations, and colony foundation in two group-hunting Myrmicine ants (Hymenoptera: Formicidae: Pheidologeton). Advances in Myrmecology, E. J. Brill, Leiden, ed. Trager, J. C.: 355-370.

Möglich, M.

1979. Tandem calling pheromone in the genus Leptothorax (Hym., Formicidae): Behavioral analysis of specificity. J. Chem. Ecol. 5: 35-52.

MÖGLICH, M. AND B. HölLDOBLER

1975. Communication and orientation during foraging and emigration in the ant Formica fusca. J. Comp. Physiol. 101: 275-288.

Möglich, M., U. Maschwitz and B. Hölldobler

1974. Tandem calling: a new kind of signal in ant communication. Science 186: 1046-1047.

Moser, J. C. AND M. S. BLUM

1963. Trail marking substances in the Texas leaf-cutting ant: Source and potency. Science 140: 1228.

Pasteels, J. M., J. L. Deneubourg and S. Goss

1987. Self-organization mechanisms in ant societies (I): Trail recruitment to newly discovered food sources. From Individual to Collective Behaviour In Social Insects (J. M. Pasteels and J. L. Deneubourg, eds.), 155-176, Birkhäuser, Basel.

Peacock, A. D., F. L. Waterhouse and A. T. Baxter

1955. Studies in Pharaoh's ant Monomorium pharaonis (L.) 10. Viability in regard to temperature and humidity. Entomologists' Monthly magazine 86: 294-298.

Peeters, C. ANd R. Crewe

1987. Foraging and recruitment in ponerine ants: Solitary hunting in the queenless Ophthalmopone berthoudi (Hymenoptera: Formicidae). Psyche 94: 201-214.

Petal, J.

1972. Methods of investigating the productivity of ants. Ekol. polsk. 94: 9-22.

Pricer, J. L.

1908. The life history of the carpenter ant. Biological Bulletin, Marine Biological Laboratory, Woods Hole, 14: 177-218.

Quinet, Y. AND J. M. Pasteels

1987. Description et évolution spatio-temporelle du réseau de pistes chez Lasius fuluginosus. Actes Coll. Ins. Soc. 4: 211-218.

RaIGNiER, A. AND J. van Boven

1955. Etude taxonomique, biologique et biométrique des Dorylus du sousgenre Anomma (Hymenoptera, Formicidae). Annales du Musée Royal du Congo Belge, n.s. 4, Sc. Zool., 2: 1-359.

RetTenmeyer, C. W.

1963. Behavioral studies of army ants. Kansas University Science Bulletin, 44: 281-465.

Riley, R. G., R. M. Silverstein, B. Carrol and R. Carrol

1974. Methyl 4-Methylphyrole-2-Carboxylate: A volatile trail pheromone from the leaf-cutting ant Atta cephalotes. J. Ins. Physiol. 20: 651-654. 
Robertson, P. L.

1971. Pheromones involved in aggressive behaviour in the ant, Myrmecia gulosa. J. Insect Physiol. 17: 691-715.

ROSENGREN, R.

1971. Route fidelity, visual memory and recruitment behaviour in foraging Wood ants of the genus Formica (Hym. Formicidae). Acta Zool. Fen. 133: 3-91.

SChNeirla, T. C.

1957. A comparison of species and genera in the ant sub-family Dorilinae with respect to functional pattern. Ins. Soc. 4: 259-298.

SChNeirla, T. C.

1965. Cyclic functions in genera of legionary ants (Subfamily Dorylinae). Proceedings of the Twelfth International Congress of Entomology, London, 1964, pp. 336-338.

Stradling, D. J.

1970. The estimation of worker ant populations by the mark-release-recapture method: an improved marking technique. J. Anim. Ecol. 39: 575-591.

SuDD, J. H.

1960. The foraging method of Pharaoh's ant Monomorium pharaonis. Anim. Behav., London, 8: 67-75.

Sudd, J. H., and N. Franks

1987. The Behavioural Ecology of Ants.Blackie, Glasgow.

TALBOT, $M$.

1957. Population studies of the slave making ant Leptothorax duloticus and its slave Leptothorax curvispinosus. Ecology, 38: 449-456.

TALBOT, $M$.

1965. Populations of ants in a low field. Ins. Soc. 12: 19-48.

Topoff, H., J. Mirenda, R. Droual and S. Herrick

1980. Behavioral ecology of mass recruitment in the army ant Neivamyrmex nigrescens. Anim. Behav. 28: 779-789.

Traniello, J. F. A.

1977. Recruitment behaviour, orientation, and the organization of the foraging in the carpenter ant Camponotus pennsylvanicus. Behav. Ecol. Sociobiol. 2: 61-79.

Traniello, J. F. A.

1978. Caste in a primitive ant: Absence of age polyethism in Amblyopone. Science 202: 770-772.

Traniello, J. F. A. and B. Hölldobler

1986. Chemical communication during tandem running in Pachycondyla obscuricornis. J. Chem. Ecol. 7: 1023-1033.

Traniello, J. F. A. And A. K. Jayasuriya

1986. The fire ant, Solenopsis invicta, as a successful "weed". J. Chem. Ecol. 7: 1023-1033.

TSCHINKEL, W. R.

1981. Chemical communication in the primitive ant Aneuretis simoni: the role of the sternal and pygidial glands. Chemistry and Biology of Soil Insects (J. Eder and H. Rembold, eds.), 515-585-588, Verlag Peperny, München. 
Verhaeghe, J. C., P. Champagne and J. M. Pasteels

1980. Le recrutement alimentaire chez Tapinoma erraticum (Hym, Form.). Biol.-Ecol. méditerranéenne 7: 167-168.

VOSSELER, $\mathbf{J}$.

1905. Die Ostafrikanische Treiberameise. Der Pflanzer 1: 284-302.

WALLIS, D. I.

1964. The foraging behaviour of the ant Formica fusca. Behaviour 23: 149-175.

WAY, M. J.

1954. Studies of the life history and ecology of the ant Oecophylla longinoda Latreille. Bull. Ent. Res. 45: 93-112.

WehNer, R., R. D. HaRKNeSS AND P. SChMid-HemPel

1983. Foraging Strategies in Individually Searching Ants. Cataglyphis bicolor (Hymenoptera: Formicidae). Gustav Fischer Verlag, Stuttgart, New York.

WiLSON, E. O.

1962. Chemical communication among workers of the fire-ant Solenopsis saevissima (Fr. Smith). 1. The organization of mass foraging. 2. An information analysis of the odour trail. 3. The experimental induction of social responses. Anim. Behav. 10: 134-164.

WiLson, E. O.

1976. A social ethogram of the neo-tropical arboreal ant Zacryptocerus varians (Fr. Smith). Anim. Behav. 24: 354-363.

WILSON, E. O.

1986. Caste and division of labour in Erebomyrma, a genus of dimorphic ants (Hymenoptera: Formicidae: Myrmicinae). Ins. Soc. 33: 59-69.

WILSON, E. O. AND B. HölLDOBLER

1985. Caste-specific techniques of defense in the polymorphic ant Pheidole embolopyx (Hymenoptera: Formicidae). Ins. Soc. 32: 3-22.

Zakharov, A. A.

1978. Estimate of the population numbers in the complex of formicaria. Zool. Zh. 57: 1656-1662. 

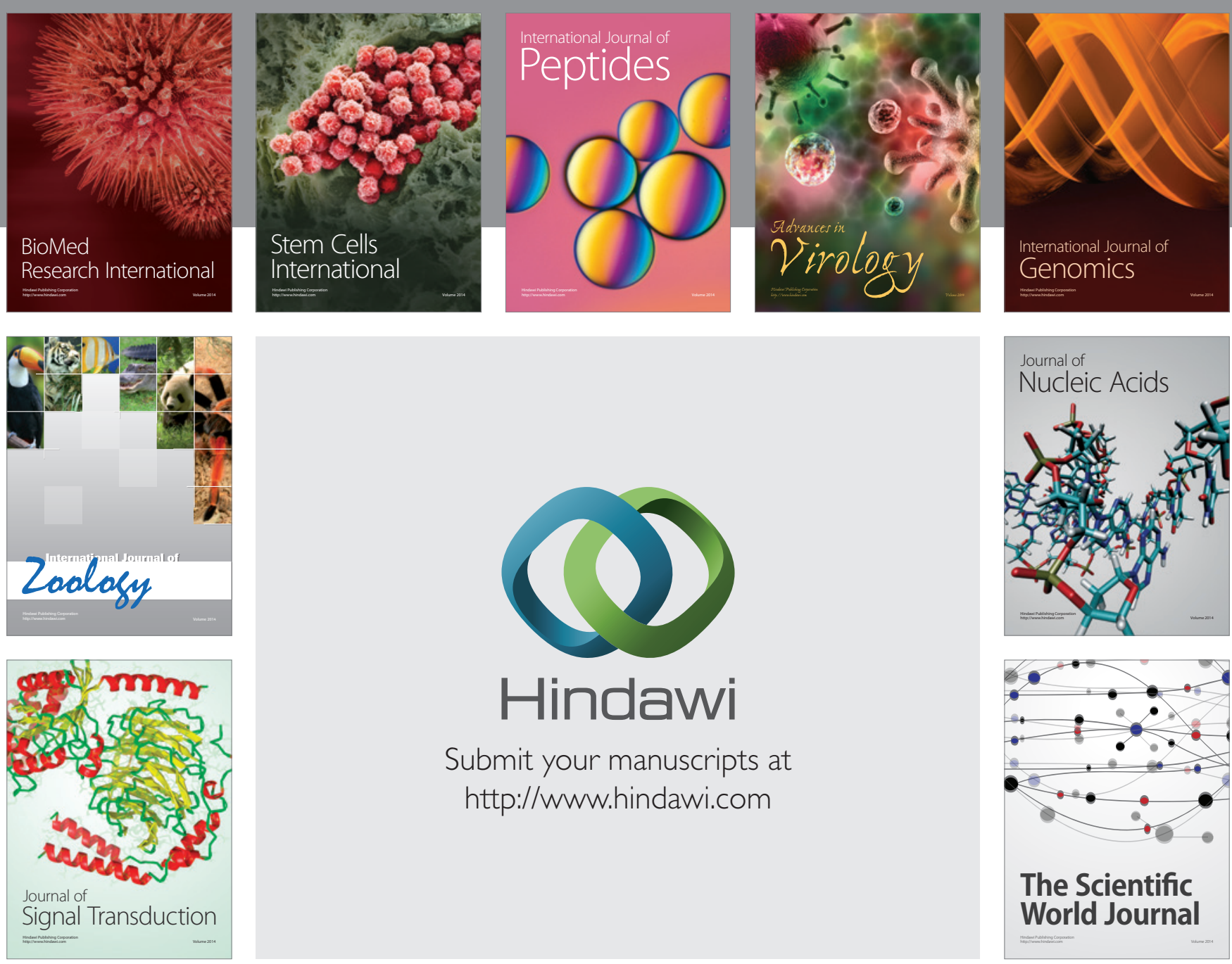

Submit your manuscripts at

http://www.hindawi.com
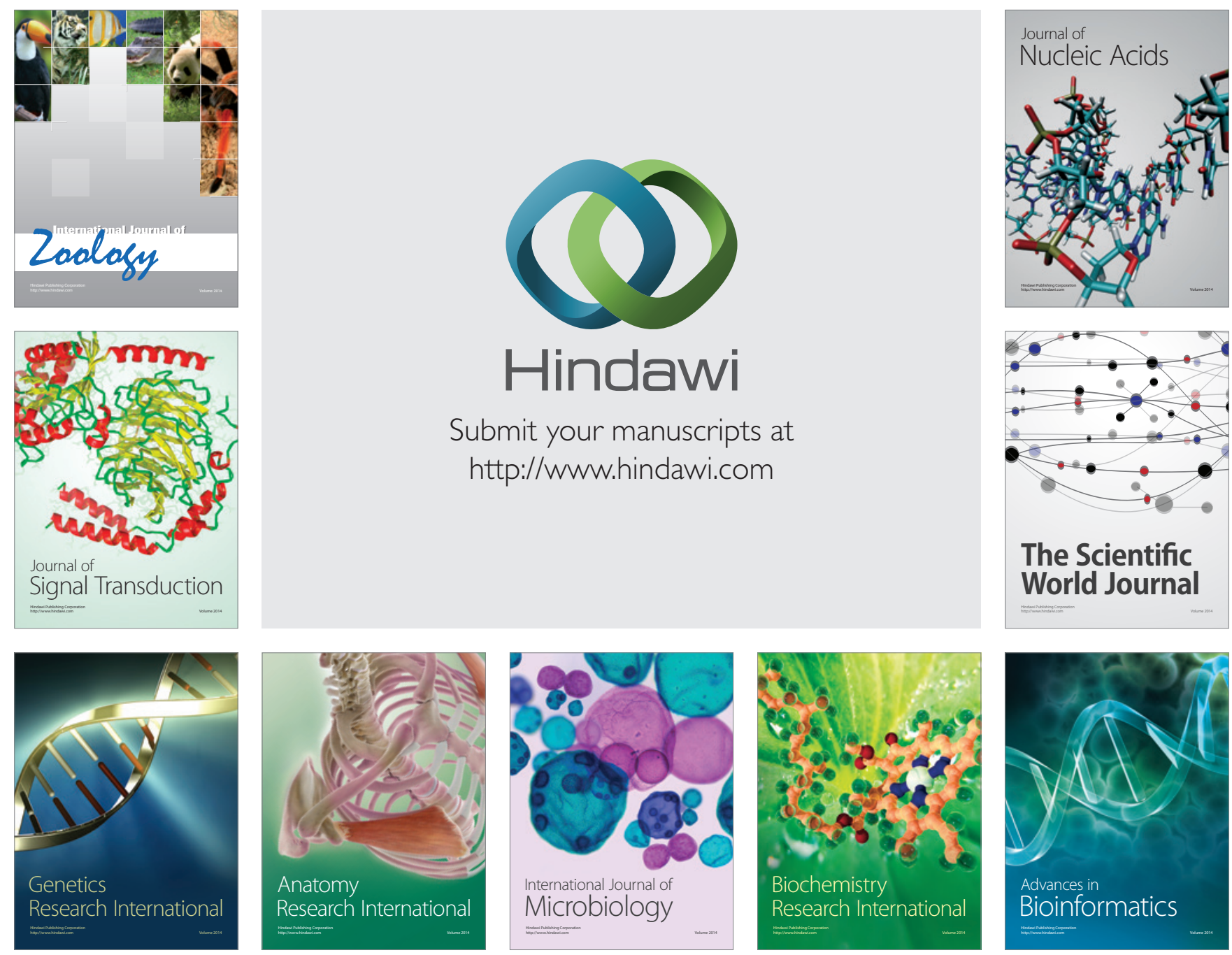

The Scientific World Journal
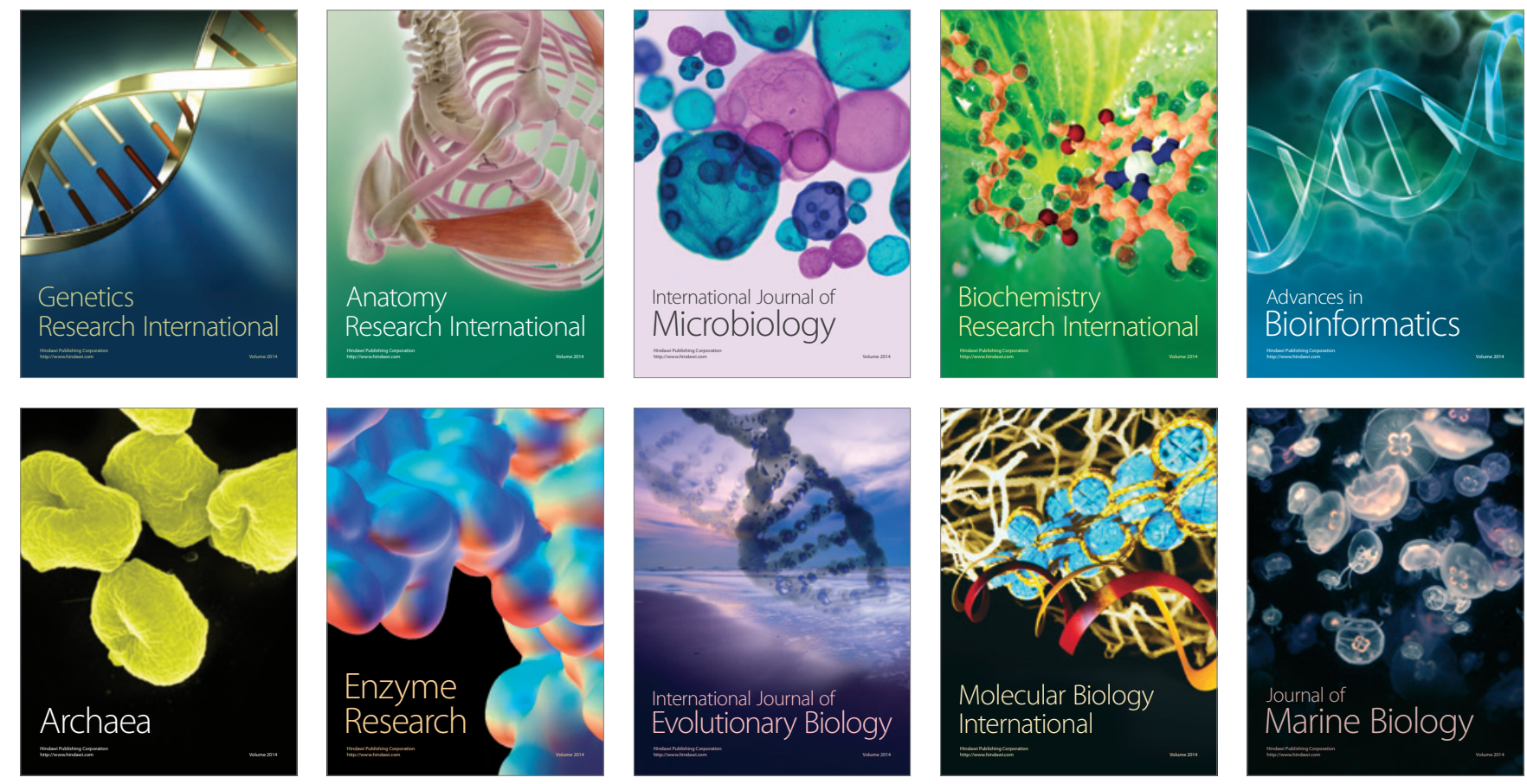